\title{
Strategies for Teaching Textile, Clothing and Designing in Zimbabwe: a Case Study of Two Universities of Technology
}

\author{
Felisia Chimbindi \\ Chinhoyi University of Technology, Zimbabwe. Orcid: oooo-0oo2-8069-7180. \\ Email:SRembe@ufh.ac.za
}

\begin{abstract}
Textile, Clothing and Design programmes' provision to students with diverse academic backgrounds in universities of technology in Zimbabwe has led to various concerns raised by the stakeholders emanating from curriculum implementation approaches, such as students' failure, drop out and prolonged completion of programmes. This study therefore, sought to examine teaching strategies used to cater for the students in provision of the programmes in 2 sampled universities. The study adopted post-positivism paradigm and used mixed method research approach that integrated concurrent qualitative and quantitative procedures in data collection, analysis and interpretation. Questionnaire, interview and document analysis were used to collect data from 36 lecturers, 2 quality assurance directors, 2 faculty deans of studies, 2 chairpersons and 6 lecturers. Collected data were analyzed using statistical and non-statistical procedures. The study revealed that lecturers used various teaching strategies to cater for the students, despite the absence of university curriculum implementation policy.
\end{abstract}

Keywords: Diverse academic backgrounds, Textile, Clothing and Design programmes.

\section{Introduction}

The lecturers who teach TCD degree programmes are supposed to have specialized in the area of Textile and Clothing to a higher level above the degree level, (UNESCO \& ZIMDEF, 2005; Gwati, 2014). They should also possess a teaching qualification (Muzenda \& Duku, 2014; Mutepfa, Mpofu \& Chataika, 2012). They are supposed to have been exposed to various teaching methodologies and assessment techniques that can be used to cater for students' diversity. It is assumed that if one has a teaching qualification, one may be able to cater for student diversity by using appropriate teaching and assessment methodologies (Chessman, 2007; Mather \& Muchatuta, 2011). The teaching methodologies may include group discussions, problem based learning, forum discussions, project based learning, simulations and peer tutoring (Jones, Ceotzee, Bailey \& Wickham, 2008).

Various concerns have been raised pertaining to the provision of TCD programmes at tertiary level in Zimbabwe. Some TCD stakeholders have raised concern that performance of students in the TCD programme has been unsatisfactory, resulting in high failure rate in some courses and poor performance in others, in the universities of technology (Muzenda \& Duku, 2014; OECD, 2009). For instance, the students' graduation rates from the universities ranged from $68 \%$ to $70 \%$ in $2010,62 \%$ to $66 \%$ in 2011 and $60 \%$ to $62 \%$ in 2012 due to student drop outs and failures (Directorate of quality assurance and graduate studies Report, 2013).

(c) AesthetixMS 2016. This Open Access article is published under a Creative Commons Attribution Non-Commercial 4.0 International License (http://creativecommons.org/licenses/by-nc/4.o/), which permits non-commercial re-use, distribution, and reproduction in any medium, provided the original work is properly cited. For citation use the DOI. For commercial re-use, please contact editor@chitrolekha.com 
Concerns have also been raised by stakeholders that despite the training received by university lecturers, it is not clear whether they are using the delivery strategies that cater for students' diversity in the implementation of the programmes, given that most of those who are not performing well are trained teachers (The Sunday Mail, 2013; Coltart, 2012; UNESCO, 2012; UNESCO \& ZIMDEF, 2005). The same stakeholders have also raised concerns that the performance of students with qualifications such as NC, "O" level and "A" level does not meet the expectations of industrialists during their attachment, as they lack the required skills (The Sunday Mail, 2013; Coltart, 2012; Jones, Coetzee, Bailey \& Wickham, 2008; OECD, 2008; McInnis, 2003; UNESCO-UNEVOC, 2013). It is therefore, not clear whether lecturers are using curriculum delivering methodologies to ensure that students with diverse academic backgrounds are catered for in the implementation of the TCD programmes.

Inclusive education entails a practice of curriculum implementation that takes into account the students' diversity through development of effective methods of learning and teaching that support all types of students in the classroom, regardless of physical ability, gender, cultural background, religion or beliefs, or political affiliation (Mathar \& Muchatuta, 2011; Dalton, Mckenzie, \& Kahonde, 2012). This study differs in that it seeks to establish differentiated curriculum implementation strategies that cater for every student in a class that comprise students with diverse academic backgrounds such as TCD university classes. Students from diverse backgrounds respond and understand the academic world differently due to their different prior learning environments (Rizvi, 2014; Ely \& Thomas, 2001).

There are various teaching approaches that can be utilized by innovative lecturers in order to develop teaching strategies to effectively cater for students from diverse backgrounds. Such teaching strategies encompass a wide range of instructional approaches and teaching methodologies like direct instruction indirect instruction, interactive instruction, experimental and independent instructional approaches. Use of a specific instructional approach guides the choice of teaching methodologies by the instructor. However, predominant use of one of the approaches need to be evaluated and reconsidered as educators need to recognize the limitations of the approach for developing students' abilities, skills and attitudes required for critical thinking, for interpersonal or group learning, and for effective catering for students with diverse academic backgrounds. Therefore, students' understanding of affective and higher level cognitive objectives may require the use of instructional approaches associated with other strategies (Tkachenko, Bratland \& Johnson, 2016; Opertti \& Belalcaza, 2008; Buzda \& Ali, 2011; Margolin, 2011 in Smith et al., 2016; Saskatchewan, 1991).

The instructors should also be able to find solutions when they face challenges in their work as curriculum implementers (Ethel, 2007). These should be provided with the opportunity to train the untrained and retrain the trained regularly throughout the instructors' career life. Further training of lecturers is necessary in order to meet the ever complex student diversity entering higher education institutions and the ever increasing industrial demands.

Current Zimbabwean trends in the provision of TVE aim to match current worldwide approaches that emphasize creativity and innovation among students. There was introduction of polytechnical colleges to train teachers for the new TVE approach. However, studies by UNESCO and ZIMDEF (2005) and Mupinga, Burnett \& Redmann (2005) reveal that not all the teachers were further trained for the new TVE provision. Therefore, the delivery of TCD programmes in universities of technology in Zimbabwe may be led by teachers who were trained for the old model TVE. On one hand, most of the trained teachers left the country for greener pastures when the country experienced economic hardships (ZIMDEF AND UNICEF, 2005; Coltart 2012). Ethel 
(2007) suggests that a system of feedback be implemented to monitor deficiencies among TVE teachers. Ethel (2007) reckons that such deficiencies may be compensated through seminars, workshops and in-service training. Due to the diverse students entering the TCD programmes in universities of technology, it is ideal to examine the teaching strategies employed by the TCD universities' lecturers to cater for students from diverse academic backgrounds.

\section{Theoretical framework}

The cultural capital and differentiated instruction theoretical frameworks guided the researcher to understand teaching strategies used to cater for students with diverse academic backgrounds in the provision of TCD programmes at university level.

The study used the Cultural Capital theory by Bourdieur (1986) which is based on the premise that educational attainment is determined by class inequalities and class reproduction in advanced capitalist societies. Cultural reproduction relates to the link between original class membership and the eventual class membership and how the link is mediated by education (Sullivan, 2002). The TCD students with different academic backgrounds have different levels of knowledge and skills in the Textile, Clothing and Design field. Bourdieu emphasizes that the education system assumes one's possession of cultural capital (Sullivan, 2002; Lizardo, 2011; Lareau, 2003). Also the level of subject content knowledge and pedagogic content knowledge among the lecturers affect the lecturers' delivery practices and the depth of subject content knowledge delivered to the students. The theory also recognizes that the institutional support affect the success of strategies used to cater for the students with diverse academic backgrounds at university level.

The study was also guided by differentiated instruction model by Tomlinson (2005), who says that students learn best when their teachers accommodate the differences in their readiness levels, interests, and academic profiles in curriculum implementation, with the objective of taking full advantage of every student's ability to learn. The differentiated instruction theory stresses that instructional approaches should vary and be adapted to cater for individual students in classes comprising students from diverse backgrounds (Hall, Strangman \& Meyer, 2003; Tomlinson, 2003). The model requires teachers to be flexible in their approach to teaching and adjust the presentation of information to meet the needs of students. Tomlinson's theory identifies three elements of the curriculum that can be differentiated namely; content, process and products. Adaptation of teaching methodologies impact on level of content taught and on types of products produced leading to achievement of set programmes' learning outcomes. Such teaching methodologies, according to Hall et al. (2003), may include big question teaching, designing learning centres/ stations, project oriented instruction, curriculum overlapping, and tiered assignments.

The rationale behind differentiated instruction is Piaget's constructivist theory, Vygostsky's zone of proximal development and Gardener's theory of multiple intelligences (Wilson, 2012; Noble, 2004). According to Piaget (1970) in Ojose (2008) theory, students interact with objects and events available in the physical and social environment and thereby comprehend the features held by such objects or events using the process of assimilation, accommodation and equilibration. Students therefore, construct their own conceptualizations and use those conceptualizations to generate solutions to problems. Therefore, university lecturers should use appropriate teaching strategies to create teaching and learning environments that allow students to generate knowledge and conceptualize processes. Barrett (2017) views the concept of a "Europe 
of knowledge" presented by the European Commission in 1997 as directly relevant to the disciplines of international education and political economy. This drives all nations to seek explanations for institutional education change. In pursuit of global competitiveness in the TCD knowledge economy, it has been considered relevant to examine the teaching strategies used by the university lecturers to cater for students with diverse academic backgrounds.

\section{Statement of the problem}

The Zimbabwean universities of technology are continuously expanding the provision of TCD programmes despite the challenges that are being faced by the implementers and the students. Muzenda \& Duku (2014), OECD (2009) and most TCD stakeholders raise concern that the programme implementers have failed to cater for variance in students' academic qualifications which has impacted on the performance of students resulting in high students drop outs, student failure in some courses, and poor performance in other courses. The Financial Gazette (2003); The Sunday Mail (2013) \& Coltart, (2012) note that the performance of most students with qualifications such as NC, "O" level and "A" level (TCD) do not meet the expectations of industrialists. The textile and clothing stakeholders also raise concern, through ATF, ILO \& UNESCO (2012) and UNESCO \& ZIMDEF (2005), that, despite the training received by university lecturers, it is not clear whether the TCD lecturers are using the delivery strategies that cater for students' diversity in the implementation of TCD programmes.

It is not quite clear how university TCD programmes are being implemented to cater for students with diverse academic backgrounds. This study therefore, sought to find out teaching strategies used by lecturers to cater for students with diverse academic backgrounds in the provision of TCD programmes.

\section{Research question}

1 How do university lecturers deliver TCD curriculum to cater for students with diverse academic backgrounds?

\section{Research objective}

The study sought to examine teaching strategies used by TCD university lecturers to ensure that all the students from diverse academic backgrounds are catered for.

\section{Delimitations}

The study was conducted in two universities of technology in Zimbabwe that offer TCD degree programmes. Participants comprised quality assurance directors, TCD deans, heads of departments, lecturers, and students from the two universities of technology. 


\section{Methodology}

\section{Research paradigm}

The study adopted Post-positivism paradigm, the paradigm relies on multiple methods of quantitative and qualitative orientation as a way of capturing as much of the reality of the study phenomenon as possible (Mackenzie \& Knipe, 2006; Toledo-Pereyra \& Luis, 2013; O'Leary, 2005).

\section{Research Approach}

The study adopted a mixed method approach which enabled the researcher to effectively synthesize ideas from respondents on teaching strategies used to cater for students from diverse academic backgrounds as it minimizes the limitations of both quantitative and qualitative research approaches (Creswell, 2014).

\section{Research Design}

The concurrent triangulation design was implemented as in this study as it provides a basis for triangulation of data as results from one method (quantitative or qualitative) can help to inform the other method.

\section{Population}

The population comprised the 2 universities of technology that offer TCD programmes in Zimbabwe, 2 quality assurance directors, 2 textile and clothing deans, 2 textile and clothing heads of departments, 70 lecturers and 240 students.

\section{Sample and Sampling Techniques}

Purposive sampling technique was used to select participants for this study. The technique enabled the researcher to select the respondents who possessed rich data on teaching strategies used to cater for students with diverse academic backgrounds. Two universities of technology were purposively chosen for the study and 2 Quality Assurance Directors, 2 TCD Deans, 2 heads of departments, 36 lecturers and 24 students.

\section{Data Collection, Instruments and Procedures}

The researcher made use of questionnaire, face-to-face semi structured interviews, focus group discussions and document analysis to gather data on strategies used to cater for students from diverse academic backgrounds in the provision of TCD programmes in universities of technology in Zimbabwe.

\section{Validity, reliability and member checking}

In quantitative data, validity was achieved through careful sampling, appropriate instrumentation and appropriate statistical analysis of the data. To ensure reliability for this study, the instruments were edited by the supervisor and a group of critical friends that included PhD students and graduates. The team reviewed the instrument items with regard to readability, clarity, format, ease and adequacy of items to ensure consistency and replicability of data gathered using the designed questions. The researcher returned to some study respondents for them to comment on whether the interpreted data were in congruent with their own experiences (member checking).

\section{Ethical considerations}

The consideration of ethics in research is important because research participants in any study should be protected from harm (Grays, 2014). To ensure protection of participants from harm, 
80 | The Chitrolekha Journal on Art and Design, Vol. 1, No. 2, 2017

the researcher secured relevant documentation that included introductory letter, permission letter and also ensured voluntary participation of respondents in the study.

\section{Data Analysis}

The collected data was analysed using statistical (SPSS) and non-statistical methods (classified into themes).

\section{Findings}

In response to how the lecturers deliver TCD curriculum to cater for students with diverse academic backgrounds, the lecturers indicated that they used teaching strategies that included instructional approaches and teaching methodologies. Most lecturers, 25 (69.4\%) said they employed the instructional approach of providing feedback and correction, $22(61.1 \%)$ said they used modeling and demonstrating skills, and 21 (58.3\%) said they motivated students through engagement with personal interest to cater for students with diverse academic backgrounds in the provision of TCD programmes. Few lecturers, 15 (41.7\%) lecturers indicated that they used modeling problem solving teaching strategy, the other $15(41.7 \%)$ lecturers claimed that they engaged scaffolding student learning through guided practice and support, $14(38.9 \%)$ lecturers indicated that they provided opportunities for students to think aloud during lessons, another 14 (38.9\%) lecturers noted that they provided alternative representation of teaching and learning materials using multimedia, illustrated texts, simplified texts or captioned videos, and another 14 (38.9\%) lecturers said they involved organization and connection of knowledge, skills and values to promote generalization in their TCD classes to cater for students' diverse needs.

The least number of lecturers, 12 (33.3\%) indicated that they used identification of key vocabulary for explicit instruction, another $12(33.3 \%)$ said they provided alternative opportunities for students to represent their learning, 11 (30.6\%) utilized explicit systematic instruction, 10 (27.8) indicated that they used cross curricular and naturally occurring learning opportunities to enhance individual learning goals, another 10 (27.8\%) said they provided opportunities for generalization and maintenance, 9 (25\%) noted that they utilized levels of promoting concepts, 8 $(\mathbf{2 2 . 2} \%)$ said they employed frequent cumulative review and one lecturer indicated that he/ she used teaching approach that encouraged inter-student demonstrations. These included the use of technology, augmentative and alternative communication systems to cater for the students with diverse academic backgrounds to enhance individual learning goals.

The lecturers also indicated the teaching methodologies they used as another strategy to teach the students from diverse academic backgrounds. The highest number of lecturers 31 (86.1\%) indicated that they used lecture method, $24(66.7 \%)$ said that they used group discussion, 20 (55.6\%) lecturers indicated that they used problem solving, and the other 20 (55.6\%) lecturers said they used research project teaching methodology in their classes. Eighteen $(50 \%)$ lecturers indicated that they used field trips to teach the students. Fewer lecturers, 5 (13.9\%) said they used guest lecturers and each of the 2 lecturers indicated that they used interactive lecture methodology and other teaching methodologies in teaching the students.

The responses reflect that the lecturers were using various strategies in teaching the TCD students, with the majority of them using lecture method, group discussion, problem solving, and research project. Lecture method, used by most lecturers limit students' involvement in a lesson since it is teacher centered (Margolin, 2011 in Smith et al., 2016). Integration of teaching methodologies by the lecturers provides students with wider opportunities for participation in 
order to understand subject content. The study results also reveal that lecturers employed various instructional approaches for effective interaction between the lecturers and students, and between students and the subject content. Use of teaching strategies that enable lecturers to engage higher levels of interactive teaching and learning yield better results in terms of catering for student diversity, especially those with diverse academic backgrounds.

The study results also show that the most used instructional approaches and teaching methodologies match the design and practical based courses which dominate in the TCD universities' programmes. Hattie (2009) and Shrader \& Helmke (2015) emphasize that teaching begins from the known to the unknown. Thus lecturers should base their teaching and learning approaches on the background knowledge possessed by the students. The lecturers also need to be highly knowledgeable of various teaching approaches, their strengths and weaknesses as well as their complementarities in order to make right choices of approaches appropriate for students from diverse backgrounds (Ross \& Ziemke 2016). The interviews carried out with quality assurance directors, deans, chairpersons, lecturers and students, revealed the following data.

QAD2 pointed out that:

Like l said in the first part, LCD is practical in that there is visual recognition of things for students to pick up and comprehend. In terms of simulation, we have taught students in terms of who they are. Also students have been attached with textiles companies and chemical plants and they are free to swap companies. The students are connected to lecturers because they mix during attachment visits. We talk to students across the board to be able to pick up students with different backgrounds and assist them.

The quality assurance directors commented that they assumed the diverse students are treated in the same way during the teaching and learning processes although the lecturers were using some teaching approaches that reflected accommodative practices. Project presentations and industrial assessment visits carried out by the lecturers enabled the lecturers to attend to students' different needs for enhancement of their learning.

\section{TCDL2 unveiled that:}

Demonstrations will actually help those students who may not have a strong practitioner's background or those students who have not worked in production industry for a long time. Lecture method also covers much and gives you a chance to talk to them about many things that they may have missed maybe as a result of lack of experience. The use of peer presentation allows the students to interact among themselves. It allows them to bridge the various gaps between the students from different backgrounds.

TCDL5 stated the same aspect of using group discussion and tutorials to effectively achieve teaching and learning goals among all the students. TCDL6 observed that catering for the students was not always done as all the students were exposed to similar examination at the end of the semester. Tomlinson (2005) notes that the use of differentiated instruction strategy in delivering curriculum to students from diverse academic backgrounds requires differentiation of questions, assignments and assessments to cater for the needs of students and fulfil expected programme outcomes.

TCDL6 echoed that: 
Normally, we don't usually cater for the diverse academic backgrounds, simply because at the end of the semester they write the same exam and the assessment criteria is the same for all despite their diverse academic backgrounds.

The students also gave their views on the teaching strategies used to cater for students from diverse academic backgrounds.

SFG1 confirmed that:

The methods are relevant, though there is need for research on the lecturers. Some of them do give us very little information. The methods help for further research rather than depending on lecturer notes. Research also helps in extension of concepts and learning.

The results from the interviews carried out with the quality assurance directors, deans of studies, chairpersons and students confirmed the lecturers' views that the teaching strategies used for TCD classes were effective because they involved students' participation and that way they catered for students' different backgrounds. The effectiveness of the teaching strategies was determined by whether the strategies were designed to cater for the diverse needs of students with regard to their various academic backgrounds or to deal with students' different abilities. However, the effectiveness of the adopted teaching methodologies and instructional approaches were said to be hindered by lack of adequate resources, inadequate lecturer training in catering for student diversities, subject in-depth content knowledge, and lack of technological skills by the lecturers to integrate ICT in curriculum implementation.

The challenge of inadequate resources led to challenges of selecting relevant teaching methods to cater for students' needs and affected smooth flow of lessons as some students did not understand the planned concepts. The study finding is in line with Musuku \& Muchemwa (2015), Nguku, (2012, 2013); Olasumbo \& Toyin, (2009) observation that universities in Zimbabwe and in other African countries were poorly resourced in teaching and learning resources such as infrastructure, materials and human resources. This means that responsive institutional support is critical for effective programmes provision to cater for different needs of the students. Therefore, the teaching strategies employed were mostly effective for equipping students with basic skills but they were not effective in adequately enhancing design innovative skills and delivering in-depth subject content knowledge among all the students.

\section{Conclusions}

The study found that there was inadequate university support to enable lecturers, faculty managers, and support staff to implement curriculum implementation strategies to cater for students with diverse academic backgrounds in delivering of TCD programmes at university level. However, there were pockets of good practice in the way lecturers delivered TCD programmes noted in the two universities of technology despite the challenges experienced in teaching and learning of the TCD students with diverse academic backgrounds. These included lecturers implementing diversified curriculum implementation practices without appropriate training, differentiating of teaching and learning methodologies, and working overtime. Despite the lecturers' commitment to cater for the students from diverse backgrounds, it is critical for the universities to consider coming up with curriculum implementation policy for appropriate guidance in designing curriculum delivering strategies to cater for students who join universities from diverse backgrounds such as those with diverse academic backgrounds. 


\section{Recommendations}

- This study suggests that the higher education institutions should offer improved flexible modes of programmes' study, offer e-learning platforms, and continuous evaluation of practices to maintain high quality standards in the teaching and learning of students.

- University institutions should support and organize staff development programmes focusing on updating lecturers' subject content knowledge and skills and those that address teaching and learning approaches to cater for students from diverse backgrounds.

- There should be interactive participation of all members of TCD departments, students and university management in designing effective curriculum implementation strategies to cater for students who enter university education from diverse backgrounds. This enables institutions to come up with a universal programmes provision that directs curriculum implementers (lecturers) to effectively deliver the programmes.

\section{References}

ATF, ILO \& UNESCO. (2012). Proposed Indicators for Assessing Technical and Vocational Education and Training. Inter- Agency Working Group on TVET Indicators. UNESCO.

Barrett, B. (2017). Background on Higher Education Policy in Europe. In: Globalization and Change in Higher Education. Palgrave Macmillan, Cham

Bourdieu, P. (1986). The Forms of Capital. In Handbook of Theory and Research for the Sociology of Education. Edited by: Richardson J. New York: Greenword.

Chessman, A. (2006). Catering for difference: institutionalising a program for gifted Students in a NSW comprehensive high school. State of NSW, Department of Education and Training, Curriculum K-12 Directorate.

Chinhoyi University Directorate of Quality Assurance and Graduate Studies (2013). Online Website www.cut.ac.zw. Retrieved 27-11-2015

Coltart, D. (2012). Education for employment, developing skills for vocation. Speech At the African Innovation Summit, 5-7. Retrieved from African Brains Website: http://www.youtube.com/watch? Retrieved 16-04-2015.

Creswell, J. W. (2014). Research Design. International Student Edition. Qualitative,Quantitative and Mixed Methods Approaches. London: SAGE.

Dalton, E. M., Mckenzie, J. A., Kahonde, C. (2012).The Implementation of Inclusive Education in South Africa: Reflections arising from a workshop for teachers And Therapist to Introduce Universal Design for Learning. African Journal of Disability, 1(1),12-20. Online website: http://dx.doi.org/10.4102/ajod.vi1.13.Retrieved 21-02-2015.

Ely, R. J. \& Thomas, D. A. (2001). Cultural Diversity at Work. The Effects of Diversity Perspectives on Work Group. Processes and Outcomes. Administrative Science Quarterly, 46(2), 229-273. Online website http://www.jstor.org/about/terms.html. Retrieved 23-02-2015.

Ethel, I. E. (2007).Quality Assurance in the teaching examination of Vocational and Technical Education in Nigeria. College Student Journal Publisher, 41(3), 37-45.

Financial Gazette, (2003, December, 8). Zimbabwe Chaos in the Classroom.

Financial Gazette. Online website. http://www.developmentgap./aweapon.html. Accessed 5/24/2014. 
Grays, D.E. (2014). Doing Research in the real world. Third Edition. London: Sage.

Gwati, L. C. K. (2014). The Legal Framework for Quality Assurance in Higher Education in Zimbabwe. Zimbabwe Council for Higher Education Conference on Quality education 2014, University of Zimbabwe. Higher Education.

Hall, T., Strangman, N., \& Meyer, A. (2003). Differentiated instruction and Implications for UDL implementation. Wakefield, MA: National Center on Accessing the General Curriculum. Online website: http://www.cast.org/publications/ncac/ncac_diffinstructudl.html. Retrieved 21-01-2015.

Jones, B., Ceotzee, G., Bailey, T. \& Wickham, S. (2008). Factors that facilitate Success for Disadvantaged higher education students. An investigation into Approaches used By REAP, NSFAS and selected higher education Institutions. Research and academic Development. Online website: www.reap.org.za. Retrieved 22-06-2016.

Lareau, A. (2003). Unequal childhoods: Class, race and family life. Berkely: University of Califonia Press.

Lizardo, O. (2011). Pierre Bourdieu as a post cultural theorist. Cultural Sociology,5(1), 1-22.

Mackenzie, N. \& Knipe, S. (2006). Research Dilemmas: paradigms, methods and Methodology. Issues in Educational Research. 16:193-205. online website: www.iier.org.au/iier16/mackenzie.html. Retrieved 2612-2015.

Masuku, S. \& Muchemwa, S. (2015). Occupational stress among university lecturers: A case of Zimbabwe. $U$. S. A.: David publishers, 5(4), 258- 266.

Mather, G. \& Muchatuta, M. (2011). How to teach with inclusive practice. Learning Through Diversity. Macquarire University. Faculty of Business and Economics. Online website: http: //www.mq.edu.au/Itc/resources.htm

McInnis, C. (2003). From marginal to mainstream strategies: responding to student Diversity in Australian universities. European Journal of Education, 38(4), 387-400.

Mupinga, D. M., Burnett, M. F. \& Redmann, D. H. (2005). Examining the purpose of Technical Education in Zimbabwe high schools. International Education Journal, 6(1), 75-83. http://iej.cjb.net. Retrieved 29-032015 .

Mutepfa, M. M., Mpofu, E. \& Chataika, T. (2012). Inclusive Education in Zimbabwe: Policy, Curriculum, Practice, Family and Teacher Education Issues. Childhood Education, 83(6), 342-346.

Muzenda, V. \& Duku, N. (2014). Skills Lecturers Possess for Quality Delivery of the Clothing and Textiles Curriculum. Mediterranean Journal of Social Sciences, 5(16), 446-452.

Nguku, E. (2013). Course Analysis and Gaps Identification in Selected Textile and Clothing Training Institutions in East - Southern Africa. ACTIF, ICIPE. Nairobi: African Cotton and Textile Industries Federation. Online website: http://www.cottonafrica.com/. Retrieved 11-02-2015.

Noble, T. (2004). Integrating the revised Blooms Taxonomy with multiple Intelligences. A planning tool for curriculum differentiation. Online website http//www.tcreco Rd.org/content.asp?Contentld=11520. Retrieved 23-08- 2016.

OECD, (2008).Tertiary Education for the Knowledge Society. Thematic Review of Tertiary Education: Synthesis Report. Online website: ww.oecd.org/newsroom/40556222.pdf. Retrieved 22-06-2015.

Olasumbo, O. A. \& Toyin, A. F. (2009). Work family conflict, job satisfaction and Labour turnover intentions among state university lecturers. Nigeria: Higher Education.

O'Leary, Z. (2004). The Essential Guide to Doing Research. London: SAGE.

Ross, D. B. \& Ziemke, L. (2016). Promising Literacy practices for students with Interrupted formal education in achieving competence with academic Language across disciplines. Fisher College of education. Faculty articles. Online website: http//nsuworks.nova.edu/fse_facarticles/242. Retrieved 24- 11-2016. 
Rizvi, S. (2014). Use of Islamic, Islamicised and National Curriculum in a Muslim Faith School in England: Findings from an Ethnographic Study. International Handbook of Learning, Teaching and Leading in Faith- Based Schools. Dordrecht: Springer Science plus Business Media.

Saskatchewan Education (1991) Instructional approaches. A framework for Professional practice. London: Klogan Page

Smith-Jackson, T., Pak, R., Johnson, K., McLaughlin, A., \& Rovira, E. (2016, September). The HFES Diversity Task Force: Advancing the HFES Vision of Inclusion. In Proceedings of the Human Factors and Ergonomics Society Annual Meeting, 6o(1), 422-424). Sage CA: Los Angeles, CA: SAGE Publications.Online website: http://www.hfes.org/web/directory\%26yearbook/2015officers. Html. Retrieved 21-07-2016.

Sullivan, A. (2002).Bourdieu and education: How useful is Bourdieu's Theory for Researchers? Netherlands: The Netherlands Journal of social Sciences, 38(2).

Tkachenko, E.; Bratland, K.; \& Johnson, J. S. (2016). Culturally Diverse students in Higher Education: Challenges and possibilities within academic literacy Practices. Intercultural Communication in educational settings. Sweden: Scandinavian Journal of Intercultural Theory and Practice, 3(2), 234-245.

Toledo- Pereyra \& Luise, H. (2013). Principles of Research: From Idea to Publication. New York: Nova Science Publishers Inc.

Tomlinson, C. A. (2003). Deciding to teach them all. Educational Leadership, 61(2), 6-11

Tomlinson, C. A. (2005). Grading and Differentiation: Paradox or good practice? Theory into Practice, 44 (3), 262-269.

UNESCO. (2012). Guidelines for recognition, validation, accreditation of the Outcomes of non-formal and informal learning. Geneva: UNESCO.

UNESCO - UNEVOC. (2013). Revising global trends in TVET: Reflections on theory And practice. UNESCO. Online website: www.unevoc.unesco.org. Retrieved 13-04-2016.

UNESCO \& ZIMDEF. (2005). Ministry of Higher and Tertiary Education. Report on Technical and Vocational Education and Training. Policy Review Framework.

Wilson, W. J. (2012). The truly disadvantaged: The inner city, the underclass, and Public Policy. University of Chicago Press.

Zhuwao, P. (2013). Boosting the Performance of Zim Assert Success. The Sunday Mail 31 July 2013.

Mrs Felisia Chimbindi Nee Saranavo is a full time lecturer at Chinhoyi University of Technology in Zimbabwe and holds a Doctor of Philosophy Degree in Education with University of Fort Hare, South Africa and Master's Degree in Technical Education (Textiles, Clothing and Design) with University of Zimbabwe. 